Voitsekhivska L. ${ }^{1}$, Borsolyuk L. ${ }^{2}$, Ohrimenko Yu. ${ }^{3}$, Verbytskyi S. ${ }^{4}$, Shelkova T. ${ }^{5}$ Institute of Food Resources of NAAS, 4 Yevhena Sverstiuka Str., Kyiv, 02002, Ukraine e-mail:1-3,5meatipr@.ukr.net, ${ }^{4}$ verb@ipr.net.ua

ORCID: ${ }^{1} 0000-0001-7595-1845,{ }^{2} 0000-0002-8137-6020,{ }^{3} 0000-0002-5910-1370,{ }^{4} 0000-0002-4211-3789$, ${ }^{5} 0000-0001-5168-5888$

\title{
Influence of biologically active compounds on the stability of the fat complex of poultry meat of mechanical rolling during storage
}

Goal. To study the influence of biologically active compounds on the process of lipid oxidation of the fat complex in poultry meat of mechanical rolling (PMMR) during storage. Methods. Research of acid and peroxide numbers of model samples of PMMR was carried out by employees of the department of technology of meat products according to GOST 314702012 «Poultry meat, by-products, and semi-finished products from poultry meat. Methods of organoleptic and physicochemical research». The method of determining the thiobarbituric number is based on the formation of colored substances as a result of the interaction of fat oxidation products with 2-thiobarbituric acid and on the measurement of the color intensity on the spectrophotometer. The object of research was PMMR with the addition of the following biologically active compounds: water and fat green tea extract, water and fat rosemary extract, dihydroquercetin. Results. The influence of biologically active compounds on the oxidizing properties of the PMMR fat complex was studied. The results of the determination of acid and peroxide numbers during the storage of the studied model samples and control for 120 days indicated the effectiveness of the selected antioxidants. As antioxidants they used natural extracts in the following quantities: fatsoluble rosemary $-0.1 \%$; water-soluble rosemary $-0.07 \%$; fat-soluble and water-soluble green tea $-0.05 \%$; dihydroquercetin $-0.025 \%$. It was found out that these compounds inhibit oxidative processes in $3.7-5.2$ times. Conclusions. The obtained research results testify to the expediency of using biologically active compounds to reduce oxidative damage in PMMR during storage.

Key words: antioxidants, natural extracts, oxidative processes.

DOI: https://doi.org/10.31073/agrovisnyk202009-09

The poultry processing industry plays a significant role in providing consumers with high-quality animal products. In recent years, the global poultry market has expanded significantly and become more competitive. The requirements for the assortment, quality and shelf life of these products have increased [1-3]. An important task for manufacturers of the meat industry today is the production of high quality products and the rational use of meat raw materials, in particular MDPM. Taking into account the fast growth rates of the poultry processing, the MDPM production volume is constantly growing, therefore, the problems of its long-term storage becomes relevant [4]. In addition, the production of MDPM is practically a waste-free technology and, due to its low cost, is an affordable raw material, and the presence of up to $15 \%$ of protein in its composition makes its widespread use possible throughout the world.

Technological features of the manufacture of MDPM cause the oxidative damage of the lipid fraction due to the presence of bone marrow elements with a significant content of phospholipids, cholesterol, and heme pigments. Depending on the mechanism of oxidative processes, various oxidation products are formed - peroxides, free radicals and low molecular weight decay products, which provide a rancid taste to fats and which reduce the nutritional value of meat products. Therefore, domestic and foreign scientists paid much attention to the stabilization problem of the possible inhibition of lipid oxidation, in particular, MDPM as a fat-containing product [3].

The cooling of meat raw materials lengthens their shelf life, but cannot completely prevent processes caused by the action of reactive oxygen modifications that initiate free radical reactions. Therefore, in the meat industry, natural and synthetic antioxidants are used to protect meat products from oxidative damage, their action aiming at blocking active radicals in chain oxidation reactions [5].

Synthetic antioxidants that have been used in the meat industry for a long time cause cytotoxicity, which leads to disruption of the metabolism in the body. That is why biochemists prefer antioxidants of natural origin, which allow you to stop the oxidation processes and, at the same time, do not have a cytotoxic effect, and are also easier to use. One of such well-researched and studied by domestic and foreign scientists antioxidants is rosemary extract [6,7].

As a result of the study and analysis of publications of contemporary researchers, for example, works of Sharyginoy Y.I. and Baydalinova L.S. dedicated to plant extracts with antioxidant effects, in particular rosemary and tea extracts [8-12], scientific and experimental confirmation of the feasibility of using plant extracts, their effect on the physicochemical parameters of hydrolytic and oxidative processes in minced meat mixes for meat products was noted.

In work [13], the feasibility of introducing a composition of extracts of rosemary and grape seed to minced duck meat to reduce hydrolytic and lipid peroxidation was shown. The obtained results prove the promising use of the composition in the technology of minced products with a high fat content. In addition, rosemary is an excellent source of vitamin E (alpha-tocopherol), another effective antioxidant that also neutralizes the action of free radicals, is the source of more than 12 types of antioxidants, contains minerals necessary to strengthen immunity: iron, magnesium, phosphorus, potassium, sodium and zinc. 
The green tea extract is often used as an antioxidant, this extract being a source of polyphenols - natural antioxidants that can be used as an alternative. The study of the influence of natural green tea extracts on the safety and quality of Turkish dry fermented sausages during ripening showed that natural antioxidants are more effective than synthetic ones, therefore they can be used in sausages to improve the quality and safety of food products $[14,15]$.

As a representative of antioxidant compounds, dihydroquercetin (DHA) is widely used. DHA is a bioflavonoid of natural origin, which has the highest antioxidant activity compared to all known exogenous antioxidants, including vitamins $E, A, B, C, D, K$, beta-carotene. It is not synthesized in the human body, so it is necessary to use the products in which it is contained. In addition, the use of DHA will allow the production of health-improving food products, since the positive effect of bioflavonoids on human health has been proven by long-term experimental and clinical studies of medical institutions [16]. Numerous literary sources and published results of research by scholars confirm the feasibility of using the selected natural antioxidants for long-term storage of fat-containing products, especially meat, as their presence in products is perceived positively by consumers [17].

The main cause of oxidative damage to meat and meat products is lipid peroxidation caused by active oxygen modifications. The degree of oxidative changes in fats is judged by the magnitude and dynamics of changes in peroxide and acid numbers.

The acid value (AV) of fat is determined by the free fatty acids contained in it. The acidity of fat is an indicator of its freshness. An increase in the acid number of fat during storage indicates the onset of hydrolytic fat spoilage.

Peroxide value (PV) characterizes the content of peroxides in fat. Fatty acids during long-term storage of fat are oxidized by atmospheric oxygen with the formation of intermediate peroxide compounds, so the accumulation of peroxides can be used to judge the initial stage of oxidative damage.

Since the action of antioxidants is planned to be studied for a long time, it is important to trace their effect on the formation of secondary oxidation products. This can be done by analyzing the thiobarbituric value (TBV). The TBV indicator reflects the development and depth of oxidative changes in the fat phase of meat products by the quantitative content of malondialdehyde, the formation of which is considered one of the adverse consequences of lipid peroxidation. An absolute TBV of less than $0.5 \mathrm{mg} / \mathrm{kg}$ indicates the stability of the lipid fraction during storage, an increase in concentration to values greater than $0.5 \mathrm{mg} / \mathrm{kg}$ indicates some oxidation, and values above $1.0 \mathrm{mg} / \mathrm{kg}$ indicate deep oxidative changes.

The aim of the research is to study the effect of biologically active compounds on the kinetics of lipid oxidation of the fatty complex in MDPM during storage.

Materials and research methods. Studies of the acid and peroxide numbers of fat of model samples of MDPM were carried out in accordance with GOST 31470-2012 «Poultry meat, edible offal and semi-processed products. Methods for organoleptic and physico-chemical examinations» [18]. The quality of MDPM during storage was evaluated by the accumulation of secondary products of oxidative spoilage of fat, which react with 2-thiobarbituric acid.

Results. For research, 6 samples of MDPM were prepared for freezing and storage at a temperature of minus $18{ }^{\circ} \mathrm{C}$. The composition of the samples was introduced by antioxidants in such concentrations:

- fat-soluble extract of rosemary (RF) - $0.1 \%$;

- water-soluble extract of rosemary (RW) - 0.7\%;

- fat-soluble extract of green tea (TF) - 0.05\%;

- water-soluble extract of green tea (TW) - 0.05\%;

- dihydroquercetin - $0.025 \%$.

No antioxidants were added to the control sample.

The main studies were carried out in accordance with GOST 31470-2012 «Poultry meat, edible offal and semiprocessed products. Methods for organoleptic and physico-chemical examinations».

The determination of the thiobarbitural number was carried out according to the methodology described in section I of the training manual [19].

Statistical processing of the results was carried out based on the calculation of arithmetic mean values and standard error. All experimental data are the results of 5 parallel determinations.

To assess the dynamics of changes in the oxidation process, we determined the acid and peroxide numbers. The research results are shown in table.

Dynamics of the influence of biologically active compounds on the indicators of oxidative damage of MDPM samples during storage

\begin{tabular}{|c|c|c|c|c|c|c|}
\hline $\begin{array}{c}\text { Shelf life, } \\
\text { days }\end{array}$ & Control & $\begin{array}{c}\text { Dihiydro- } \\
\text { quercetin }\end{array}$ & $\begin{array}{c}\text { Rosemary } \\
\text { extract, } \\
\text { fat soluble }\end{array}$ & $\begin{array}{c}\text { Rosemary } \\
\text { extract, } \\
\text { water soluble }\end{array}$ & $\begin{array}{c}\text { Tea extract, } \\
\text { fat soluble }\end{array}$ & $\begin{array}{c}\text { Tea } \\
\text { extract, } \\
\text { water soluble }\end{array}$ \\
\hline \multicolumn{6}{|c|}{ Peroxide number, $\% \mathrm{~J}_{2}$} \\
\hline
\end{tabular}




\begin{tabular}{|c|l|l|l|l|l|l|}
\hline 0 & $0,017 \pm 0,006$ & $0,013 \pm 0,006$ & $0,013 \pm 0,006$ & $0,013 \pm 0,013$ & $0,011 \pm 0,019$ & $0,014 \pm 0,006$ \\
\hline 3 & $0,046 \pm 0,013$ & $0,018 \pm 0,006$ & $0,040 \pm 0,013$ & $0,025 \pm 0,019$ & $0,035 \pm 0,013$ & $0,021 \pm 0,013$ \\
\hline 9 & $0,035 \pm 0,019$ & $0,018 \pm 0,019$ & $0,029 \pm 0,006$ & $0,025 \pm 0,032$ & $0,022 \pm 0,013$ & $0,020 \pm 0,032$ \\
\hline 15 & $0,034 \pm 0,019$ & $0,017 \pm 0,006$ & $0,030 \pm 0,025$ & $0,026 \pm 0,025$ & $0,023 \pm 0,038$ & $0,020 \pm 0,013$ \\
\hline \multicolumn{7}{|c|}{ Acid number, mg KOH } \\
\hline 0 & $1,986 \pm 0,032$ & $1,943 \pm 0,032$ & $1,962 \pm 0,025$ & $1,973 \pm 0,032$ & $1,970 \pm 0,025$ & $1,979 \pm 0,051$ \\
\hline 3 & $2,546 \pm 0,032$ & $1,974 \pm 0,025$ & $2,154 \pm 0,044$ & $2,090 \pm 0,057$ & $2,112 \pm 0,019$ & $2,032 \pm 0,025$ \\
\hline 9 & $2,743 \pm 0,032$ & $2,253 \pm 0,013$ & $2,433 \pm 0,032$ & $2,379 \pm 0,013$ & $2,375 \pm 0,044$ & $2,298 \pm 0,057$ \\
\hline 15 & $2,923 \pm 0,032$ & $2,154 \pm 0,044$ & $2,498 \pm 0,038$ & $2,368 \pm 0,025$ & $2,328 \pm 0,032$ & $2,245 \pm 0,044$ \\
\hline
\end{tabular}

The dynamics of changes in acid and peroxide values shows that the addition of these antioxidant inhibits the process of lipid hydrolysis and has a positive effect on the rate and amount of peroxide formation and shows down oxidative processes. It was found that after 15 days of storage of MDPM, the increase in peroxide values of the tested samples with dihydroquercetin was less by $42 \%$, and with green tea water extract - by $35 \%$ compared with control samples.

Given the effectiveness of selected antioxidants, their effect on oxidative damage during long-term storage 120 days was studied.

The dynamics of PV changes during storage of MDPM samples under the action of biologically active compounds is shown in Fig. 1.

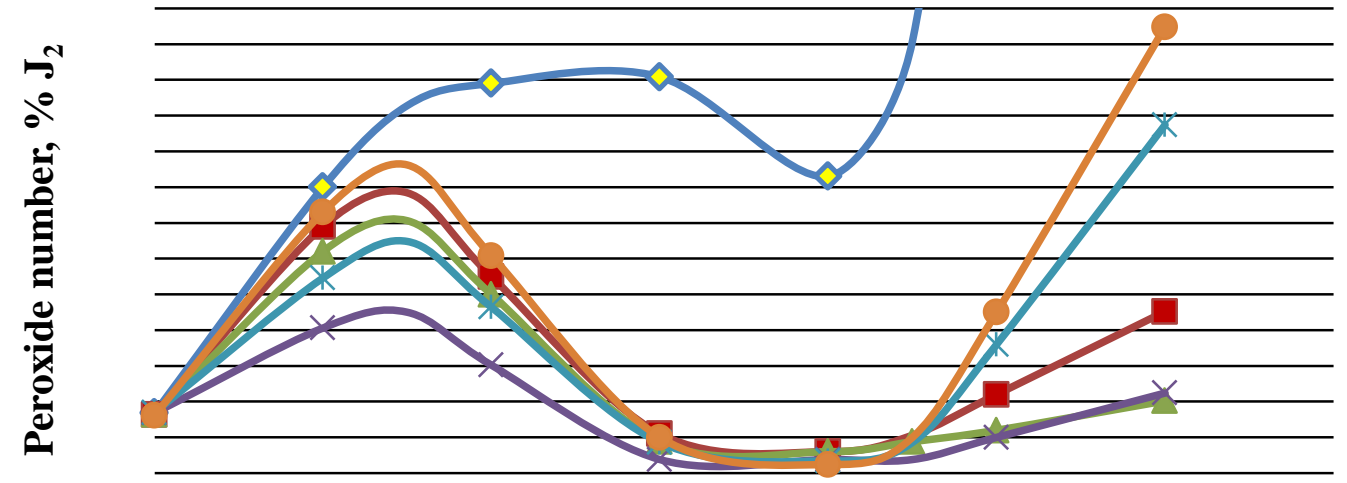

Days

$\begin{array}{lll}\underset{\text { Control }}{-} & - \text { DHA } & - \text { RF } \\ \leftarrow \text { RW } & * \text { TF } & - \text { TW }\end{array}$

Fig. 1. Dynamics of the influence of biologically active compounds on the indicators of oxidative damage of MDPM samples during storage

The dynamics of changes in the peroxide number during storage of samples of MDPM shows that the best values of peroxide number were noted from the 60th to the 90th day of storage, after which they began to grow slowly. The greatest influence of their properties onthe inhibition of the formation of hydroperoxides was shown by the extract of fat-soluble rosemary, the extract of water-soluble rosemary and dihydroquercetin.

The hydrolytic damage to the fat complex of MDPM is characterized by the acid number of fat. The results of measurements of the acid number over 120 days are shown in Fig. 2. 


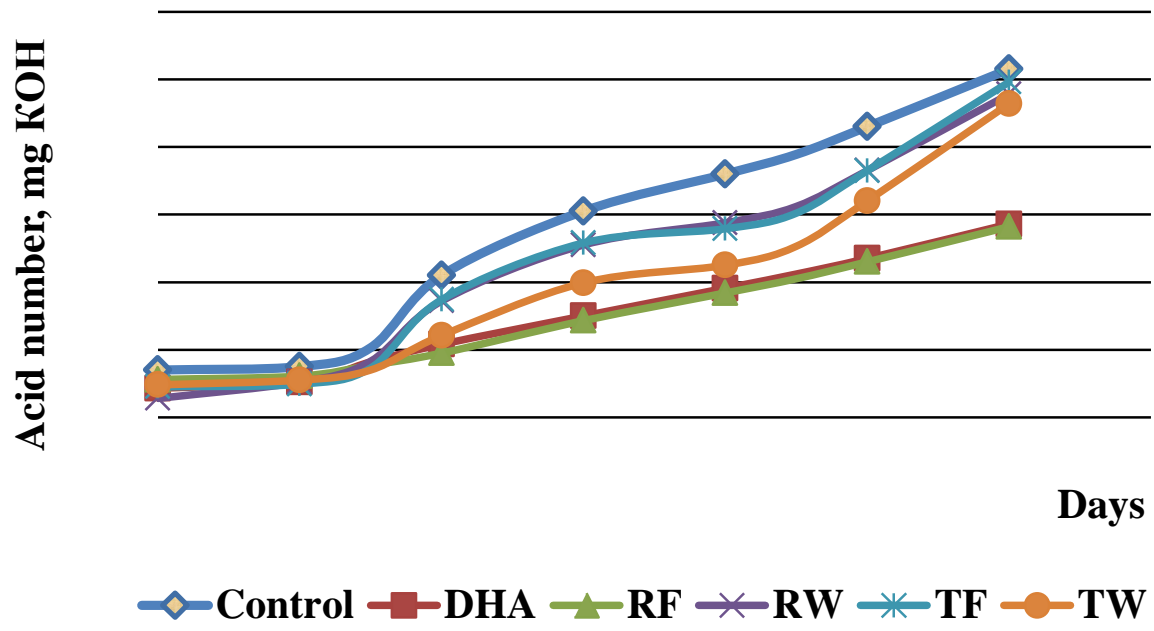

Fig. 2. Dynamics of the influence of biologically active compounds on the indicators of hydrolytic deterioration of MDPM samples during storage

The acid values dynamics shows that as a result of the addition of antioxidants, the process of hydrolysis of the fat complex slows down, but their effect begins to appear after the 30th day of storage. After the 40th day, the process of hydrolytic decomposition noticeably decreases. Especially different is the positive effect on the inhibition of the formation of hydroperoxides of antioxidants such as fat-soluble rosemary extract, dihydroquercetin, and water-soluble green tea extract. The acid index in the samples with the fat-soluble extract of rosemary and dihydroquercetin grew linearly and its average value in both cases at the end of the shelf life by 120 days was $25 \%$ lower than the value of the control sample.

The deeper oxidative changes and the formation of products of secondary fat oxidation (aldehydes, ketones) characterizes the thiobarbituric value.

The results of studies of the dynamics of the formation of secondary oxidation products are presented in Fig. 3.

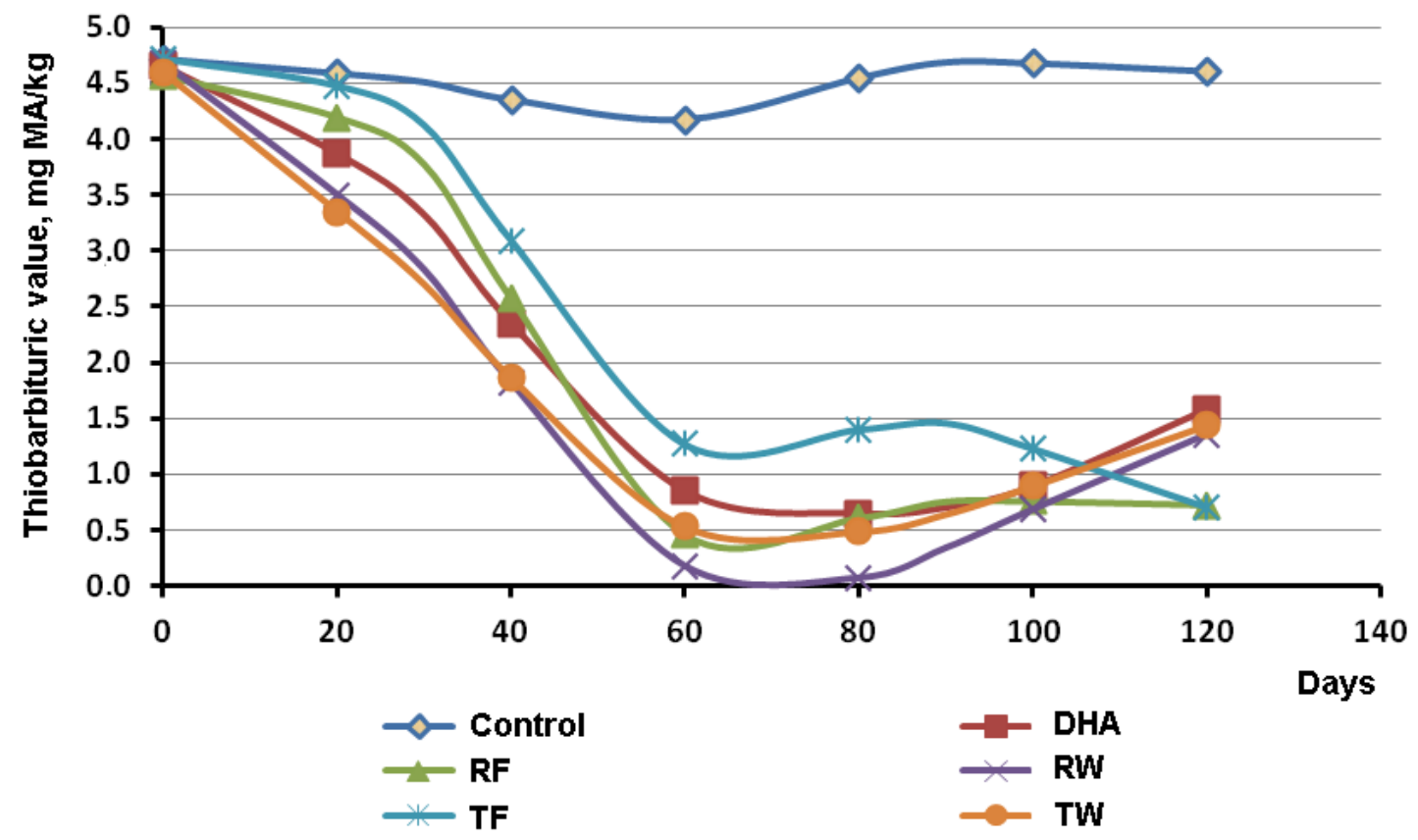

Fig. 3. Dynamics of the influence of biologically active compounds on the formation of secondary products of oxidation of the fatty complex MDPM during storage

Upon receipt of the research results, it is noted that the effect of antioxidants not only completely slowed down the growth of the thiobarbituric value, but also significantly reduced them by about $85 \%$ of the values of the control sample on the 60th day of storage. 
In the control sample, the thiobarbituric value was almost unchanged from the beginning to the end of storage. After the 100th day and until the end of storage, the indicators of thiobarbituric values of samples with antioxidants, water-soluble rosemary extract, water-soluble green tea extract increased their values by 1.5 times, and samples with oil-soluble rosemary extract and green fat-soluble tea extract, on the contrary, decreased by 1.2 times.

A generalization of the obtained results of changes in oxidative processes during storage of MDPM confirms the correct choice of selected studied biologically active compounds.

\section{Conclusion}

When studying the effect of antioxidants such as fat-soluble rosemary extract, water-soluble rosemary extract, fat-soluble green tea extract, water soluble green tea tea extract, dihydroquercetin on the oxidation of lipids of the fatty complex MDPM during 120 days of storage, their high antioxidant effect on oxidative deterioration was noted, which allows extending the shelf life of this raw material by (10-15) days.

The effectiveness of the studied antioxidants in inhibiting oxidative processes was confirmed to be (3.7-5.2) times higher than in the control sample.

\section{References}

1. Rogozhin, V.V., \& Rogozhina, T.V. (2014). Biokhimiya selskokhozyaystvennoy produktsii [Biochemistry of agricultural products]. Sankt-Peterburg: Giord. [in Russian].

2. Antipova, L.V., Berdnikov, V.L., Kalachev, R.A., \& Astanina, V.Yu. (2005). Modifikatsiya retseptur varenykh kolbas iz myasa ptitsy [Modification of formulations for cooked sausages from poultry meat]. Meat industry, 7 , 36-40. [in Russian].

3. Gonotskiy, V.A., \& Fedina, L.P. (2004). Dinamika kachestvennykh kharakteristik myasa ptitsy pri khranenii [The dynamics of the qualitative characteristics of poultry meat duringstorage]. Meat industry, 6, 28-32. [in Russian].

4. Baydalinova, L.S., \& Sharygina, Ya.I. (2009). Stabilizatsiya lipidov bystrozamorozhennykh myasnykh polufabrikatov [Lipid stabilization of quick-frozen meat semi-finished products]. News of KSTU, 15, 78-83. [in Russian].

5. Semenova, A.A. (2011). Primenenie pishchevykh dobavok v myasnoy promyshlennosti [The use of food additives in the meat industry]. Food ingredients: raw materials and additives, 1, 31-35. [in Russian].

6. Sharygina, Ya.I., \& Baydalinova, L.S. (2011). Fitoekstrakty v sovremennom proizvodstve myasnykh zamorozhennykh polufabrikatov [Phytoextracts in the modern production of frozen meat semi-finished products]. Electronic scientific journal SPbSU-NiPT series "Processes and Food Production Equipment", 1, 218-228. [in Russian].

7. Sharygina, Ya.I., \& Baydalinova, L.S. (2011). Ispolzovanie ekstraktov rozmarina kak antioksidantov v tekhnologii myasnykh zamorozhennykh polufabrikatov [The use of rosemary extracts as antioxidants in the technology of frozenmeat semi-finished products]. Scientific and technical journal "University News. Food Technology", 2-3, 35-37. [in Russian].

8. Baydalinova, L.C., \& Sharygina, Ya.I. (2008). K voprosu stabilizatsii lipidov pri proizvodstve bystrozamorozhennykh myasnykh polufabrikatov (pp. 39-42). [To the question of lipid stabilization in the production of quick-frozenmeat semi-finished products]. Materialy mezhdunar. nauch.-prakt. konf. "Biotekhnologicheskie sistemy kak odin iz instrumentov realizatsii gosudarstvennoy programmy razvitiya selskogo khozyaystva i regulirovaniya rynkov selskokhozyaystvennoy produktsii, syrya i prodovolstviya na 2008 - 2012 gody» [Materials of the international. scientific and practical conf. "Biotechnological systems as one of the tools for implementing the state program for the development of agriculture and regulation of agricultural products, raw materials and food markets for 2008 - 2012"]. DonSAU. [in Russian].

9. Petrov, O.Yu. (2018). Primenenie antioksidantov v tekhnologii myasnykh produktov. Aktualnye voprosy sovershenstvovaniya tekhnologii proizvodstva $i$ pererabotki produktsii selskogo khozyaystva [The use of antioxidants in the technology of meat products. Topical issues of improving the technology of production and processing of agricultural products. Article in the journal - materials of the conference]. Mari State University, 20, 293-296. [in Russian].

10. Baydalinova, L.C., \& Sharygina, Ya.I. (21 - 23 Okt., 2008). Rastitelnye ekstrakty dlya stabilizatsii lipidov bystrozamorozhennykh myasnykh polufabrikatov [Vegetable extracts for lipid stabilization quick-frozen meat semi-finished products]. (pp. 281 - 283). Trudy VI mezhdunar. nauch. konf. "Innovatsii v nauke $i$ obrazovanii - 2008» [Proceedings of the VI Intern. scientific. conf. "Innovation in Science and Education - 2008"]. Kaliningrad. [in Russian].

11. Bozhko, N.V., Tyshchenko, V.I., Pasichnyi, V.M. et al. (2017). Analiz vplyvu ekstraktiv rozmarynu ta vynohradnykh kistochok na okyslennia lipidiv miasa kachky pekinskoi [Analysis of the effect of rosemary extracts and grape bones for oxidation of meat lipids Peking duck]. Eastern European Journal advanced technologies, 4/11 (88), 4 - 9. doi: 10.15587/1729-4061.2017.108851

12. Bozkurt, H. (2006). Utilization of natural antioxidants: Green tea extract and Thymbraspicata oil in Turkish dryfermented sausage. Meat Science, 73, 442 - 450. doi: 10.1016/j.meatsci.2006.01.005

13. Kostyrya, O.V., \& Korneeva, O.S. (2015). O perspektivakh primeneniya digidrokvertsetina pri proizvodstve produktov s prolongirovannym srokom godnosti [On the prospects for the use of dihydroquercetin in the production of products with prolonged shelf life]. Bulletin of VGUIT, 4, 165 - 170. doi: 10.20914/2310-12022015-4-165-170. [in Russian]. 
14. Semenova, A.A., \& Nasonova, V.V. (2006). Antiokisliteli novogo pokoleniya dlya myasnoy produktsii [New generation antioxidants for meat products]. Meat industry, 2, $33-36$. [in Russian].

15. GOST 31470-2012. Myaso ptitsy, subprodukty i polufabrikaty iz myasa ptitsy. Metody organolepticheskikh i fiziko-khimicheskikh issledovaniy [Poultry meat, by-products and semi-finished products from poultry meat. Methods of organoleptic and physical and chemical research]. 2013, 07-01. Moskow: Standartinform, 2013. [in Russian].

16. Antipova L.V., Glotova I.A., Rogov I.A. Metody issledovaniya myasa i myasnykh produktov [Research methods for meat and meat products]. Moscow: Kolos, 2001. [in Russian].

17. Alghazeer, R., Suhur, S., \& Howell, N.K. (2008). Aldehyde formation in frozen mackerel (Scomber scombrus) in the presence and absence of instant green tea. Food Chemistry, 108, 801 - 810. doi: 10.1016/j.foodchem.2007.08.067

18. Maqsood, S., \& Benjakul, S. (2011). Comparative studies on molecular changes and pro-oxidative activity of haemoglobin from different fish species as influenced by pH. Food Chemistry, 124, 3, 875 - 883. doi: 10.1016/j.foodchem.2010.07.011

19. Johnston, J.E., Sepe, H.A., Miano, C.L. et al. (2005). Honey inhibits lipid oxidation in ready-to-eat ground beef patties. Meat Science, 70, 4, 627 - 631. doi: 10.1016/j.meatsci.2005.02.011 